Article

\title{
Household Water Demand in Andorra: Impact of Individual Metering and Seasonality
}

\author{
Arnaud Reynaud ${ }^{1, *}$ (D), Marc Pons ${ }^{2}$ and Cristina Pesado ${ }^{2}$ \\ 1 Toulouse School of Economics, INRA, University of Toulouse Capitole, Toulouse, France \\ 2 Sustainability Observatory of Andorra, Andorra La Vella, Andorra; mpons@obsa.ad (M.P.); \\ cpesado@obsa.ad (C.P.) \\ * Correspondence: arnaud.reynaud@inra.fr; Tel.: +33-5-61128512
}

Received: 5 January 2018; Accepted: 10 March 2018; Published: 14 March 2018

\begin{abstract}
Despite the large literature focused on residential water use, our knowledge of the impact of individual metering on household water consumption remains limited. Our work aims to fill this gap by providing the first estimate of the residential water demand function in the Principality of Andorra, where collective and individual metering coexists. Using a panel dataset covering the years 2006 to 2015, we propose estimating a domestic water demand function for the municipality of Andorra La Vella (the capital of Andorra). Our estimates reveal a price elasticity of the residential water demand equal to -0.7. Facing a price increase of 10 percent, households will react in the short run by reducing their water consumption by 7 percent. Interestingly, the price elasticity is found to be significantly different in single-family units compared to multi-family units. This may suggest a significant impact of individual metering on domestic water consumption in Andorra.
\end{abstract}

Keywords: residential water use; metering; andorra; water demand; price elasticity

\section{Introduction}

This paper focuses on residential water consumption in the Principality of Andorra. Residential water consumption is defined as the quantity of water used to cover household and related utility needs of the population through the water supply industry and self-supply, calculated as a total and per capita. Household water consumption provides a measure of the pressure on the environment in terms of water abstraction from different water sources through household use. This type of indicator is important for defining the level of development of water economy services and the degree of water accessibility to cover all household needs of the population. The indicator may also help to identify trends in household water use in a particular country. To the best of our knowledge, our paper will be the first to provide an econometric analysis of residential water demand in Andorra.

There are several reasons that call for a clear understanding of household water use. First, most national allocation regimes define domestic and human needs as the highest priority use [1] although there are a few exceptions (the Netherlands, a small number of Canadian provinces, water use in Israel, and Peru). Second, most large-scale water assessment models predict some very significant changes in household water use (or more generally in urban water use) over the next 50 years [2]. Third, water is an essential good for households in the sense that water has no good substitute for most indoor water use (personal hygiene, cleaning, etc.).

Economists have been working on household water use for some time. However, water demand modelling has taken on new importance with the need to better understand the role economic instruments (i.e., water pricing) may have to induce change in water user behavior (i.e., the reduction of water abstraction or polluted discharge). To this end, economists have developed a large number of models to predict the water demand for industrial, agricultural and domestic users. For domestic 
users, the level of knowledge is already quite advanced. Estimations of domestic water demand functions have been undertaken for a substantial number of countries around the world, and the existing literature has already been summarized and reviewed by several authors [3,4]. In Europe, household water demand functions are available for a large number of countries. However, a report by the European Environmental Agency [5] points out that most available reference studies in Europe date back 10 or 20 years and that "new case studies with primary data are required to provide fresh and relevant evidence that accounts for the socio-economic, management and technological changes that have taken place in the last 20 years". This is the main objective of our paper that provides the first econometric analysis of residential water demand in the Principality of Andorra.

Some characteristics of Andorra make the analysis of residential water use particularly interesting. The Principality of Andorra is located in the Pyrénées mountains between France and Spain. The altitude of its capital is $1013 \mathrm{~m}$ (the highest capital city of Europe). The tourism sector is highly developed and has a significant specialization in winter activities on offer. Thus, the ratio population of non-permanent to permanent is very high. According to the Andorra Statistical Office, 7.8 million people visited Andorra in 2014 (with a population of 70,540 inhabitants). Lastly, individual metering on household water consumption remains limited in Andorra, where a domestic water subscriber can indeed be either a single-family unit or a multi-family unit. In the latter case, there is typically only one collective meter for all units. We propose here to estimate a domestic water demand function using a panel dataset covering the years 2006 to 2015 for the municipality of Andorra La Vella. Our estimate reveals a price elasticity of the residential water demand equal to -0.7 . Facing a price increase of 10 percent, households will react in the short-run by reducing their water consumption by 7 percent. Interestingly, the price elasticity is found to be significantly different in single-family units compared to multi-family units. The domestic water demand is found to be more inelastic in multi-family units compared to single-family units. This suggests a significant impact of individual metering on household water use.

The remainder of this article is organized as follows. Section 2 gives a brief overview of domestic water use is Andorra. Section 3 reviews the existing literature on domestic water use in France and Spain. The following two sections, Sections 4 and 5, present the water demand approach and the empirical analysis, respectively. Finally, we summarize the main results in Section 6.

\section{Water Use and the Water Sector in Andorra}

\subsection{A Brief Presentation of Andorra}

The Principality of Andorra lies on the side of the Eastern Pyrénées mountains, between Spain and France, bordering the Spanish autonomous community of Catalonia in the south (for $63.7 \mathrm{~km}$ ), and the French departments of Ariège and Pyrénées-Orientales in the north (for $56.6 \mathrm{~km}$ ). Andorra occupies an area of $468 \mathrm{~km}^{2}$, with an average altitude of $1996 \mathrm{~m} \mathrm{[6].} \mathrm{Politically,} \mathrm{it} \mathrm{is} \mathrm{divided} \mathrm{into} \mathrm{seven} \mathrm{parishes,}$ each of which has its own local government, called the Comú.

According to the Andorran Department of Statistics, the population of Andorra was 70,570 inhabitants in 2014, of which approximately half (35,424 inhabitants) were Andorrans [6]. The other 35,146 inhabitants were foreigners, mostly from Spain (49\%), Portugal $(27 \%)$ and France $(8 \%)$. The population is concentrated mostly in the central parishes-Andorra la Vella being the most populated with 30 percent of the total population. The average age of the Andorran population is 39.5 years, which is a fraction below the European average (42.2 years).

In 2014, the Andorra GDP per capita (at current market prices) reached $€ 35,786$ [6]. Tourism and commerce are the two main pillars of Andorra's economy. Tourism brings in nearly eight million visitors per year, mostly from Spain and France. 


\subsection{Water Resources and Water Use in Andorra}

Climatic conditions and orography play a key role in the availability of water resources. Effective rainfall in Andorra was estimated to be around 283 gigalitres (GL) in 2015, with 10 percent of this amount being used for environmental purposes [7]. Effective rainfall is mainly fed by the annual rain and snow precipitations and are distributed from the highlands to the bottom of the valleys by the three main rivers (Valíra del Nord, Valíra d'Orient and Gran Valira) and their affluents [8]. As of March 2017, the Andorran Ministry of Environment reported that the volume of high-quality surface waters in the country was about 86 percent, while 8 percent was of acceptable quality, 3 percent was of poor quality and the remaining 3 percent was of very poor quality. Climate change and increasing water demands-mainly from the touristic and energy industries-may however have a detrimental impact on the future sustainability of water resources. Temperature increases and precipitation decreases due to climate change are expected to significantly affect snow resources (the main source of water in catchment areas) in coming decades, modifying both water availability and seasonality [9].

Water use can be divided into consumptive uses (domestic, agriculture and livestock, thermalism, industry) and non-consumptive uses (snow making for ski resorts, energy production and fish farming). In 2015, consumptive water use in Andorra was equal to 13.18 GL [8]. With 10.88 GL, domestic users (which include households, hotels and small commercial firms) rank first in terms of consumptive water abstraction (82.6\% of total abstraction). Agriculture and livestock rank second with 1.73 GL (13.2\%), followed by thermalism ( 0.54 GL or $4.1 \%$ ) and industry ( $0.006 \mathrm{GL}$ or $0.0 \%$ ). In 2015, non-consumptive water use in Andorra was equal to 76.97 GL [8]. With 74.48 GL, the energy production (hydroelectricity) is by far the largest non-consumptive user $(96.8 \%)$. Water used for snow production and for fish farming activities accounts for only 1.19 GL (1.55\%) and 1.30 GL (1.69\%), respectively.

\subsection{Domestic Water Use in Andorra}

The seven Andorran parishes are the public entities responsible for distributing water to final users. It remains difficult to have a clear idea of the volume of water distributed to domestic users in Andorra, first, because no consolidated figure is available, and, second, the water volumes reported often mix domestic users with hotels and/or small commercial firms. However, three parishes (Andorra La Vela, Canillo and Soldeu) have reported the percentage of the volume of water priced to domestic users in [8], which varies from 59.81 percent in Andorra La Vella to 53.59 and 33.45 percent in Canillo and Soldeu, respectively. Domestic users hence represent a substantial share of the volume of water billed to final consumers in Andorra.

In our analysis, two specificities of domestic water use in Andorra will be accounted for. Our particular focus will be on the share of multi-family units (a multi-family unit refers to a dwelling type that is a single structure consisting of one or more housing units, such as duplexes, flats and apartment buildings [10]) and on the high seasonality of domestic water consumption.

First, it is important to stress that in Andorra each water subscriber does not always correspond to a single-family unit. It is a common scenario that a group of apartments (for instance, a 10 family unit building) is considered by a water service as a "unique subscriber". For instance, in Andorra La Vella (the capital of Andorra), the 524 domestic water subscribers represent around 5200 family units. Understanding the factors that influence multi-family water consumption has previously been addressed in the existing literature, but mainly in the United States [10]. In this paper, we propose an analysis of multi-family water consumption in the specific context of Andorra.

Second, as mentioned previously, one of the main economic activities of the country is the tourism industry. The share of non-permanent residents, especially in areas close to ski resorts, is therefore particularly high. As a result, the domestic water consumption is concentrated during specific seasons of the year (especially in winter) and even during particular days of the week (weekends and holidays). We propose to explicitly identify the seasonality pattern of domestic water consumption in Andorra. 


\section{Residential Water Demand in France and Spain: A Brief Review of the Literature}

This section provides a brief review of the empirical literature on residential water demand. Since no published study on domestic water demand is available for Andorra, we focus mainly on studies undertaken in France and Spain, the two neighbors of Andorra.

In Table 1, we summarize the main findings in terms of significant drivers of the household water demand function in France and Spain. As a word of caution, it should be noted that this cross-country comparison is made difficult by the fact that variables introduced as determinants of the household water demands are not consistently defined across studies. In addition, the dependent variable may also differ between studies, some of which use water consumption per capita while others may refer to water consumption per household. However, certain general and persistent trends do emerge. In order to organize the discussion, we analyze the different groups of determinants, including water price and tariffs, household income, population characteristics, housing characteristics, and climate conditions.

Most economists working on domestic water use generally recognize that domestic water consumption reacts to changes in water prices. It is, however, usually found that the household water demand function is price inelastic, which means that water consumption decreases by less than 1 percent for every 1 percent increase in price, with the price-elasticity typically varying between -0.1 and -1.0 . In his recent meta-analysis, Sebri [11] reports for example mean and median price elasticities equal to -0.365 and -0.291 , respectively. A price inelastic water demand function is usually reported in studies focusing on France and Spain. Among all the reviewed studies, only Arbués et al. [12] have found a price-elastic household water demand. In Table 1, it appears that the range of price-elasticity is quite similar for France and Spain.

It is also widely accepted that domestic water consumption is positively correlated with income. The explanation is straightforward. A high level of income is associated with higher living standards, which could imply a higher quantity of water-consuming appliances and a higher probability for the presence of high-water demanding outdoor uses, such as lawn gardens and swimming pools. This result holds for France and Spain since all income elasticities presented in Table 1 are positive. It should also be pointed out that the income elasticity is not significantly different from zero in several studies conducted in France or in Spain (i.e., [13]).

Table 1. Price, income and main determinants of household water demand in France and Spain.

\begin{tabular}{|c|c|c|c|c|}
\hline Country & Study & Price Elasticity & Income Elasticity & Other Main Determinants \\
\hline France & Nauges and Reynaud (2001) [14] & $-0.22 ;-0.08$ & 0.01 & Housing recent (-) \\
\hline France & Nauges and Thomas (2003) [15] & $-0.40 ; 0.40$ & 0.50 & n.a. \\
\hline France & Garcia and Reynaud (2004) [16] & -0.25 & 0.03 & Household size (+) Recent Housing (+) \\
\hline France & Rinaudo et al. (2012) [17] & -0.18 & 0.42 & Temperature $(+)$ Dry days $(+)$ Secondary homes $(+)$ \\
\hline France & Binet et al. (2014) [18] & -0.35 & 0.35 & Household size $(+)$ Rainfall $(-)$ \\
\hline Spain & Martínez-Espiñeira (2002) [19] & $-0.16 ;-0.12$ & $0.30 ; 0.68$ & Temperature (+) Rainfall (-) Household size (-) \\
\hline Spain & Arbués (2004) [20] & $-0.06 ;-0.03$ & $0.07 ; 0.21$ & n.a. \\
\hline Spain & García-Valiñas (2005) [21] & $-0.55 ;-0.46$ & 0.58 & Household size $(+)$ \\
\hline Spain & Arbués and Villanúa (2006) [22] & -0.08 & 0.79 & Household size $(+)$ Temperature $(+)$ \\
\hline Spain & Martínez-Espiñeira (2007) [23] & $-0.50 ;-0.10$ & 0.00 & Temperature $(+)$ \\
\hline Spain & García-Valiñas et al. (2010) [24] & -0.06 & 0.06 & Household size (+) Age (-) Rainfall (-) Tourist (+) \\
\hline Spain & March and Saurí (2010) [25] & n.a. & 0.70 & Household size $(+)$ Age $(-)$ Density $(-)$ \\
\hline Spain & Arbués et al. (2012) [12] & $-1.31 ;-0.26$ & 0.00 & Temperature $(+)$ Age $(-)$ \\
\hline Spain & March et al. (2012) [26] & n.a. & n.a. & Age (-) Immigrant (-) Housing size (-) \\
\hline Spain & Pérez-Urdíales et al. (2016) [27] & -0.32 & n.a. & $\begin{array}{l}\text { Household size (+) Electric appliances }(+) \\
\quad \text { Water saving electric appliances }(-)\end{array}$ \\
\hline Spain & Vallès-Casas et al. (2017) [13] & $-0.14 ;-0.11$ & 0.03 & Age (-) Household size (-) Seasonal population (+) \\
\hline
\end{tabular}

n.a.: not included or not available in the study.

Some household or housing characteristics are important for explaining domestic water use in France or in Spain. Ageing is usually known to be a factor contributing to lower water consumption per capita, the other variables being held constant. This result tends to be true, especially in Spain (i.e., $[12,13,24-26])$. Most empirical studies have also found that residential demand for water is influenced by heterogeneity associated with differences in the size of the household [12]. For France and Spain, it is reported that household size affects the demand for water, in general positively 
(i.e., $[18,21,22,24,25,27])$, although a few studies have found the inverse result (i.e., $[13,19,26])$. Climate is one of the most studied drivers of domestic water demand. Indeed, it is considered that household water consumption varies depending on variables such as temperature and rainfall, which may influence the amount and/or frequency of activities that involve water-consumption (garden watering, swimming pool use and personal hygiene [28]). The climate indicators usually considered in Table 1 include rainfall (annual or in the summer, number of rainy or dry days) and temperature (maximal or average). For France and Spain, it is found that water use increases with temperature (i.e., $[12,17,19,22,23])$ or with the number of dry days (i.e., [17]). On the contrary, water consumption decreases with rainfall levels (i.e., $[18,19,24]$ ).

As discussed previously, one important characteristic of the inhabitants of Andorra is the large share of the non-resident population in relation to seasonal touristic activities, such as skiing in winter. The impact of the seasonal population on household water consumption has already been investigated in the existing literature. In France and Spain, it is usually found that the seasonal population tends to contribute to an increase per capita water consumption (i.e., $[13,17,24]$ ). This positive effect may capture the larger share of recreational water use (swimming pool, garden watering) in holiday homes.

\section{Material and Methods}

\subsection{The Water Demand Function Approach}

The water demand function approach relies on standard neoclassical economic assumptions. In particular, it is assumed that, for each consumer, there exists a continuous utility function that depends on the consumed commodity bundle. The utility of each consumer is then maximized under a budget constraint and given the prices of the commodities. Thus, the demand for a commodity is assumed to depend on the income of consumers, on the price of the commodity and on the availability and prices of all other commodities that are substitutes or complements to the commodity in question, as well as on consumer preferences.

Most scholars have made the assumption of weak separability of water with respect to other goods. Under this assumption, household water consumption will not depend on the price of other goods consumed. There is no logical difficulty in imposing separability of water with respect to other goods. First, most indoor water uses (personal hygiene, cleaning, etc.) have no good substitutes. Second, household habits may be considered constant, at least in the short run. Third, complementary goods related to domestic water consumption are typically durable equipment (washing machines, sanitary equipment, etc.) that is unlikely to be changed in the short term in reaction to a water price change. Under this separability assumption, the Marshallian demand in water can be written as:

$$
y=y^{*}(p, I, Z),
$$

where $y$ is the water consumption either per capita or per household, $p$ and $I$ denote the unit water price (representing both water supply and the sewage treatment services) and the representative household income, respectively. $Z$ is a vector of exogenous variables assumed to influence water consumption (climate conditions, household and housing characteristics, etc.).

We are especially interested in providing empirical evidence on the relationship between water price and household water consumption. A simple way to measure this relationship is to compute the price elasticity of the water demand. The price elasticity of the water demand measures the responsiveness (or elasticity) of water use to a change in water price, all other things being equal. To be more precise, it gives the percentage change in household water use in response to a 1 percent change in price (all other things being equal, i.e., holding all the other determinants of demand, such as income, constant). The price elasticity of the water demand may be written as:

$$
\epsilon_{p}=\frac{\partial y^{*}(.)}{\partial p} \times \frac{p}{y^{*}} .
$$


One implicit assumption we have made when writing Equation (1) is that water is a homogenous good. In reality, however, water that is used by households is a composite good. It consists of the direct use of water for drinking water (which in general represents a small share of the total water consumption) and the indirect use of water as a complement to different household activities (washing, cooking, hygiene, gardening, etc.). Water is, therefore, a necessity in households in a number of its uses and, as such, has no substitute, while it is not a necessity in many other of its uses. In the latter case, the demand for water is likely to be more affected by price changes. Since it is not usually possible to separate the different types of demand, the estimated elasticities are usually based on an aggregated household demand for water as depicted in Equation (1). However, alternative specifications, such as a Stone-Geary utility function, which allows us to identify a volume of water covering basic needs, have also been explored.

\subsection{Data}

\subsubsection{Domestic Water Subscribers and Family Units}

Our case study is Andorra La Vella, the capital of Andorra. According to the Andorran Department of Statistics, the total population of Andorra La Vella in 2016 was 22,128 inhabitants, representing around 30 percent of the total population in Andorra.

We have access to the individual quarterly water consumption for all domestic water subscribers ("abonat") from 2006 to 2015 in Andorra La Vella. In our sample, we observe water consumption for 1228 domestic water subscribers. In our initial sample, we had 1830 domestic water subscribers, but for 602 the water consumption was null for all quarters from 2006 to 2015. These domestic water subscribers have been excluded from the final sample. The number of domestic water subscribers has steadily increased from 986 in 2006 to 1019 in 2015.

A domestic water subscriber can be either a single-family unit (the water subscriber serves only one family unit) or a multi-family unit (the water subscriber serves two or more family units). We have 285 single-family units $(23.1 \%)$ and 947 multi-family units $(77.9 \%)$. On average, a domestic water subscriber delivers water to 10.86 units. It follows that our data provide the water consumption for a total of 13,336 distinct domestic water units, a number which can be considered as almost exhaustive compared to the registered population in Andorra La Vella (22,128 inhabitants in 2016).

The number of family units per domestic water subscriber is highly heterogeneous and varies between 1 and 159. In our sample, 520 domestic water subscribers ( $42.4 \%$ of water subscribers) have delivered water to more than 10 family units, 200 (17.9\% of water subscribers) to more than 20 family units, 31 (2.5\% of water subscribers) to more than 50 family units, and seven ( $0.6 \%$ of water subscribers) to more than 100 family units. The number of family units per domestic water subscriber has slightly increased from 10.66 in 2006 to 10.99 in 2015.

\subsubsection{Domestic Water Consumption}

We now report some basic descriptive statistics on domestic water consumption in Andorra La Vella. Our variable of interest $(W)$ is the water consumption by family unit ( $\mathrm{m}^{3} /$ quarter/unit). For a given domestic water subscriber ("abonat"), it is obtained by dividing the volume of water consumed $\left(W_{\text {Abonat }}\right)$ by the corresponding number of family units $\left(F U_{\text {Abonat }}\right)$ :

$$
W=\frac{W_{\text {Abonat }}}{F U_{\text {Abonat }}}
$$

Figure 1a gives the average water consumption per quarter by family unit from 2006 to 2015. The average water consumption per quarter over the period 2006 to 2016 per family unit is $45.25 \mathrm{~m}^{3}$ per family unit. This translates into an annual water consumption of $191 \mathrm{~m}^{3}$ per year per family unit, 
a figure higher than that reported for France and Spain (between 100 to $120 \mathrm{~m}^{3}$ per year per household for most of studies presented in Table 1).

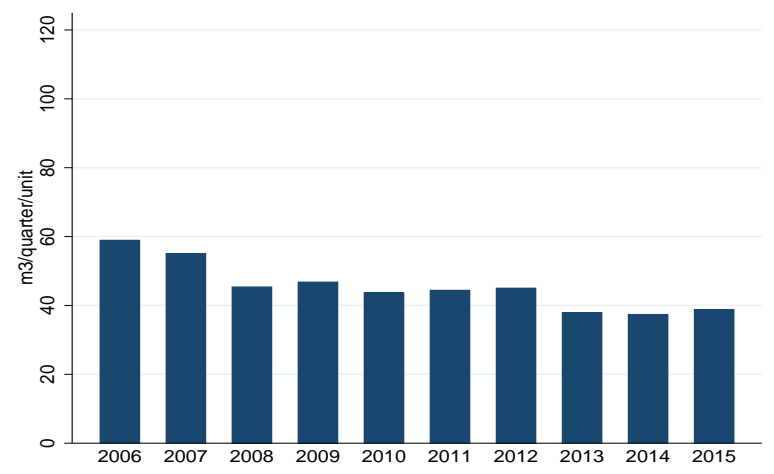

(a) All family units.

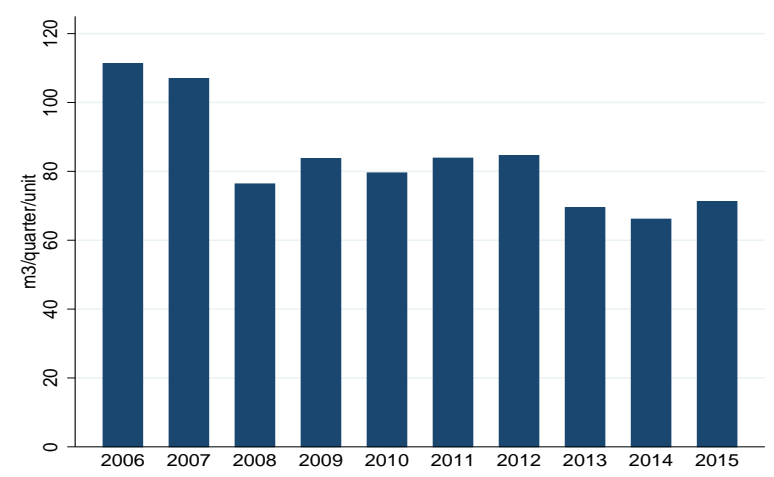

(b) Single-family units.

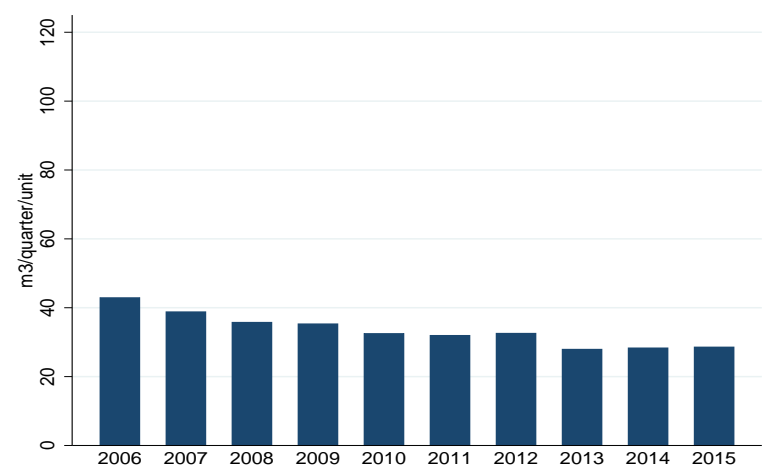

(c) Multi-family units.

Figure 1. Average quarterly water consumption by type of family unit ( $\mathrm{m}^{3} /$ quarter/unit).

Figure 1a-c gives the average water consumption per quarter by family unit from 2006 to 2011, making the distinction between single-family and multi-family water subscribers.

A clear temporal pattern emerges from Figure 1a with two different sub-periods. From 2006 to 2013 , the water consumption per quarter has decreased from $58.94 \mathrm{~m}^{3}$ per family unit in 2006 to $37.86 \mathrm{~m}^{3}$ per family unit in $2013(-35.8 \%)$. In the three most recent years, the water consumption per quarter has slightly increased (37.86, 37.39 and $38.79 \mathrm{~m}^{3}$ per family unit in 2013, 2014 and 2015, respectively). 
Not surprisingly, the average water consumption per family unit is much greater for single-family water subscribers compared to multi-family water subscribers $\left(83 \mathrm{~m}^{3}\right.$ versus $33.40 \mathrm{~m}^{3}$ per unit on average for the period 2006 to 2015), Figure 1b,c. Several reasons may explain this result. It could be related to an income effect if richer households are more likely to live in single-family units. Another explanation could be that the proportion of permanent population is greater in single-family units. The temporal pattern of the average water consumption per quarter by family unit is also quite different across single-family and multi-family water subscribers.

We now explore how seasonal effects impact on quarterly water consumption per family unit. Figure 2a gives the average quarterly water consumption per family unit (1, 2, 3 or 4 for January-March, April-June, July-September and October-December, respectively) from 2006 to 2015.

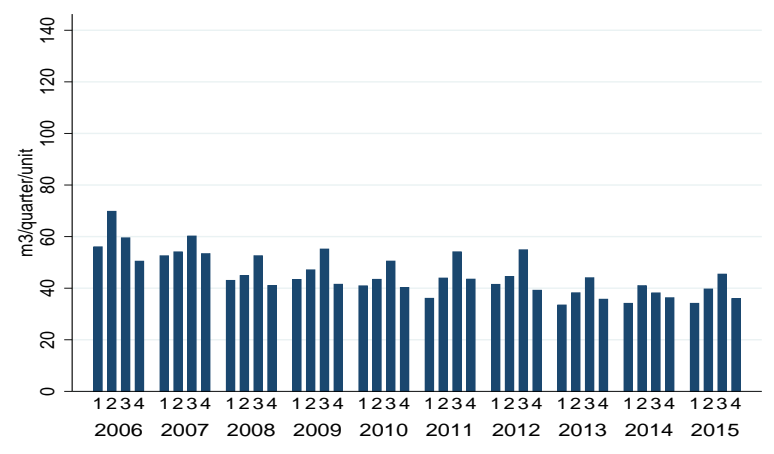

(a) All family units.

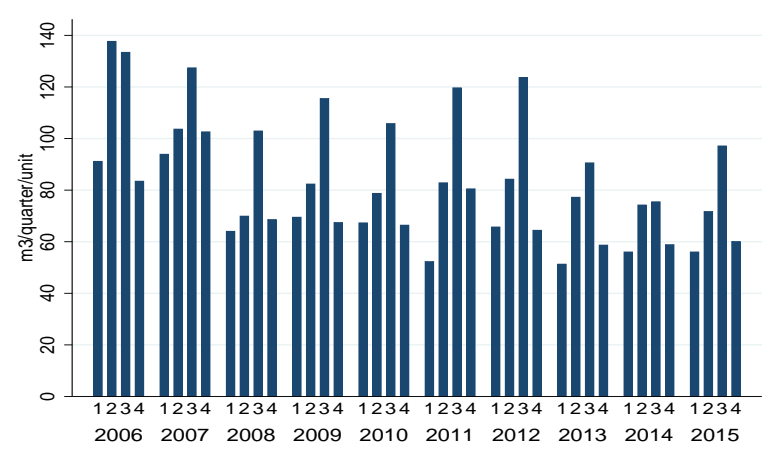

(b) Single-family units.

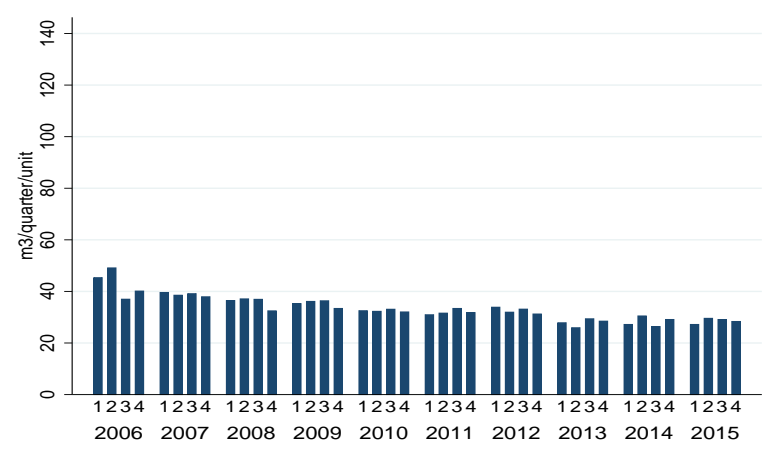

(c) Multi-family units.

Figure 2. Average water consumption per quarter by family unit (in $\mathrm{m}^{3}$ / quarter/unit). 1,2,3 or 4 for January-March, April-June, July-September and October-December, respectively. 
The average water consumption by family unit is characterized by a strong seasonality. For all years (with the exception of 2006 and 2014), the highest water consumption by family unit is observed during the third quarter (July-September).

Figure $2 b, c$ gives the average quarterly water consumption per year according to the type of family unit, e.g., single-family unit and multi-family units. Although a decreasing trend can be observed for both type of family units, there are substantial differences in terms of seasonality. In multi-family units, there is almost no evidence of seasonality in water consumption: the lowest quarterly water consumption is $32.46 \mathrm{~m}^{3}$ per unit for the fourth quarter, whereas the highest quarterly water consumption is $34.20 \mathrm{~m}^{3}$ per unit for the second quarter $(+5.38 \%)$. On the contrary, seasonality is a strong characteristic of water consumption in single-family units: the lowest quarterly water consumption is $66.42 \mathrm{~m}^{3}$ per unit for the first quarter, whereas the highest quarterly water consumption is $108.92 \mathrm{~m}^{3}$ per unit for the third quarter $(+63.96 \%)$. These differences may potentially be explained by a higher outdoor water use by single-family units (garden, swimming pool, etc.) in summer, and by a lower occupation rate of housing in summer for multi-family units (non-permanent housing).

\subsubsection{Domestic Water Pricing}

In Andorra, water users only pay for the water supply service, with the wastewater service directly funded through the Andorran budget. We have then collected the pricing schemes used for domestic users in Andorra La Vella from 2006 to 2015 for the water supply service. They are presented in Table 2.

Table 2. Pricing schemes for domestic water use in Andorra La Vella.

\begin{tabular}{|c|c|c|c|c|c|c|c|c|c|c|}
\hline & 2006 & 2007 & 2008 & 2009 & 2010 & 2011 & 2012 & 2013 & 2014 & 2015 \\
\hline \multicolumn{11}{|c|}{ Volumetric charge $\left(€\right.$ per $\left.\mathrm{m}^{3}\right)$} \\
\hline 0 to $10 \mathrm{~m}^{3}$ & 0.23 & 0.237 & 0.243 & 0.250 & 0.250 & 0.250 & 0.253 & 0.258 & 0.260 & 0.260 \\
\hline 10 to $25 \mathrm{~m}^{3} a$ & 0.415 & 0.427 & 0.438 & 0.451 & 0.740 & 0.810 & 0.814 & 0.830 & 0.850 & 0.850 \\
\hline$>25 \mathrm{~m}^{3 b}$ & 0.725 & 0.747 & 0.766 & 0.789 & 0.740 & 0.810 & 0.814 & 0.830 & 1.110 & 1.110 \\
\hline Number of blocks & 3 & 3 & 3 & 3 & 2 & 2 & 2 & 2 & 3 & 3 \\
\hline \multicolumn{11}{|c|}{ Fixed charge (€ per quarter) } \\
\hline $15 \mathrm{~mm}$ meter & 2.94 & 3.02 & 3.10 & 3.16 & 3.63 & 4.16 & 6.04 & 6.16 & 6.34 & 6.34 \\
\hline
\end{tabular}

The typical pricing scheme used in Andorra La Vela for the water supply service is a multiple block rate price with a fixed charge. From 2006 to 2009, domestic users have faced an increasing block rate with three blocks ( 0 to $10 \mathrm{~m}^{3}, 11$ to $25 \mathrm{~m}^{3}$, more than $25 \mathrm{~m}^{3}$ per quarter). From 2010 to 2013 , the second and third blocks have been merged. From 2014, the third block was set up again but with a reduced lower bound ( 21 instead of $25 \mathrm{~m}^{3}$ ). Whatever the year, domestic water subscribers face an increasing block rate. From 2006 to 2009, the marginal price increases by 80 percent from the first to the second block, and by 75 percent from the second to the third block. In 2010, the gap between the marginal price of the first and the second block has almost doubled.

Both the volumetric prices and the fixed charge have significantly increased over the period 2006 to 2015. The fixed charge per quarter for a $15 \mathrm{~mm}$ meter has increased by 116 percent, passing from 2.94 to $6.34 €$ per quarter. Although the marginal price in the first block has remained relatively stable over this period $(+11.5 \%)$, large increases for the second and third blocks should be noted $(+104.8 \%$ and $+53.8 \%$, respectively). These changes may be interpreted as a wish to use price mechanisms providing more incentive to save water for large consumers.

Overall, domestic water subscribers in Andorra La Vella from 2006 to 2015 have experienced some significant changes, both in terms of price level and in terms of the structure of pricing schemes. It is then interesting to identify if these pricing changes have resulted in some modifications of water consumption patterns. 


\subsubsection{Domestic Water Bill}

Next, we consider the average water bill paid by a family unit $(B I L L)$. The average water bill is obtained by dividing the total water bill of a domestic subscriber $\left(B I L L_{A b o n a t}\right)$ by the corresponding number of family units $\left(F U_{A b o n a t}\right)$ :

$$
B I L L=\frac{B I L L_{\text {Abonat }}}{F U_{\text {Abonat }}} .
$$

For multi-family units, we assume that the total bill paid by the water subscriber is equally divided across all family units. This appears to be the rule that is most often used in Andorra La Vella (personal communication from the Andorran Ministry of Environment). Figure 3a gives the average water bill per quarter per family unit (in €/quarter/unit) from 2006 to 2015. For the whole period, the average water bill is equal to $40 €$ per quarter per family unit. No clear dynamic pattern emerges from Figure 3a. The average water bill has first decreased from $43 €$ per quarter per family unit in 2006 to $34.6 €$ per quarter per family unit in 2010. From 2010, the average water bill has then started to increase to reach $47.6 €$ per quarter per family unit in 2015 . Since the number of family units per water subscriber is highly heterogeneous (it varies from 1 to 139), the previous figure is not very informative. Figure $3 b, c$ then present the average water bill per quarter per family unit (in € /quarter/unit) for single-family units and multi-family units, respectively. For the whole period, the average water bill paid by a single-family unit is $74.5 €$ per quarter, more than twice that paid on average by a multi-family unit ( $29.3 €$ per quarter). The water bill for a single-family unit is characterized by a very high seasonality: on average, the water bill is equal to $59.8 €$ in January-March compared to $96.9 €$ in July-September $(+62.0 \%)$. This seasonality phenomenon is not observed for multi-family units.

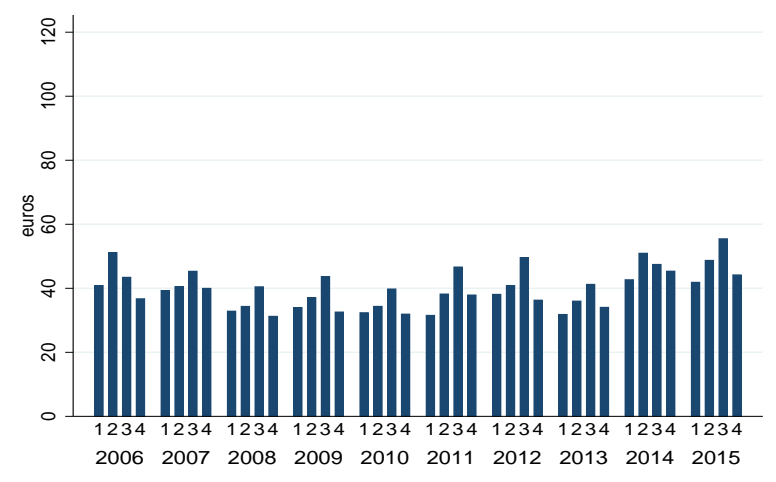

(a) All family units.

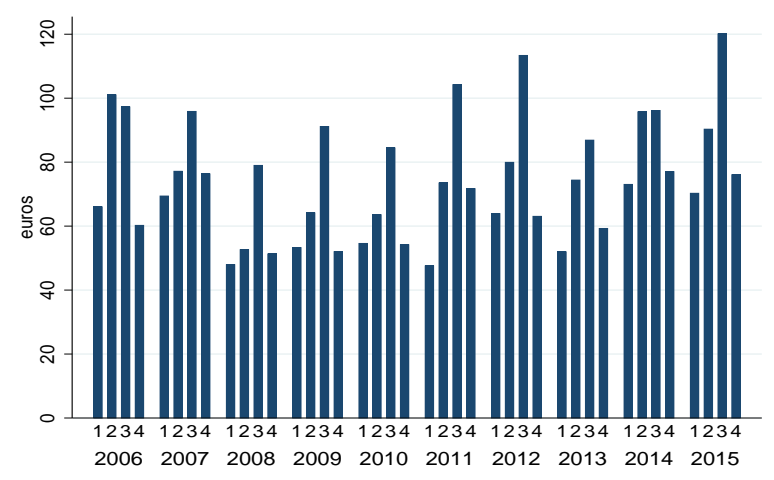

(b) Single-family units.

Figure 3. Cont. 


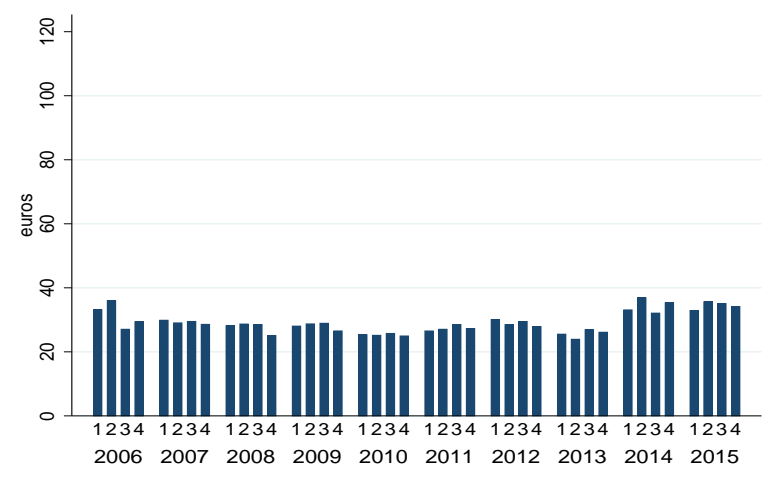

(c) Multi-family units.

Figure 3. Average water bill per quarter by family unit (in € /quarter/unit). 1, 2, 3 or 4 for JanuaryMarch, April-June, July-September and October-December, respectively.

\subsection{Other Explanatory Variables}

It is usually found that domestic water consumption is highly impacted by climatic conditions. Here, we use climate data (quarterly precipitations in $\mathrm{mm}$, average, minimum and maximum temperature in degrees) obtained from the Andorra Department of Statistics for the Roc de Sant Pere meteorological station located in Andorra La Vella. Over the period 2006 to 2015, the average quarterly precipitation has been $190 \mathrm{~mm}$, with an average temperature equal to 15.9 degrees. These two climatic indicators are highly impacted by seasonality (see Appendix A).

Ideally, we would have needed some additional variables to characterize domestic water users (income, household size, etc.). These data were not available in the individual records transmitted by the municipality of Andorra La Vella. However, we have the exact location of each water subscriber (name and number of the street where the subscriber is located). We propose then to use a fixed effects approach based on street names. Our underlying assumption is that domestic water users belonging to the same street share similar characteristics in terms of housings or income.

\section{Empirical Results}

\subsection{Model Specification}

To estimate Equation (1), a wide variety of functional forms have been applied in the water demand literature, including linear forms, semi- or double-logarithm forms and more complex forms such as the Stone-Geary specification. The existing literature is, however, not very informative concerning the specification that should be preferred. Since the double-log model is the most common specification in the residential water demand literature, we have adopted this model in order to facilitate comparisons with other studies. Furthermore, the specification implies that coefficient estimates are also elasticity estimates. Two panel data estimators may be used, namely the fixed effects model and the random effects (or error components) model. We use these two estimators to conduct some specification tests (Hausman test) in order to decide which is the most appropriate to our data.

\subsection{Endogeneity of the Water Price}

As discussed previously, the municipality of Andorra La Vella has implemented an increasing block rate (IBR) pricing structure (three blocks from 2006 to 2009 and from 2013 to 2015, two blocks from 2010 to 2012). This raises a problem of price endogeneity due to the simultaneous determination of marginal price and water demand. This problem has been addressed by estimating instrumental variables (IV) models, such as two-stage least squares [29]. The use of the average water price as an explanatory variable also raises a problem of endogeneity. Stated simply, the average price a consumer 
faces depends on his level of consumption, but this level of consumption is also affected by the average price. This simultaneity violates standard assumptions regarding independence of the error term from explanatory variables. Ordinary least squares (OLS) are in such a case inconsistent, and a specific estimation procedure is required. This simultaneity problem can be also addressed by using instrumental variables (IV) techniques. Here, in order to get unbiased price elasticities, the average water price has been first instrumentalized. As instruments, we have used the marginal price for the first and the last block, the upper bound of the first block, the lower bound of the last block, and the number of blocks. All instruments are significant, with the expected sign and the Wald test rejecting the null assumption of joint insignificant parameters (results for the instrumental price equation are available from the authors upon request). In the remainder of the paper, we use the instrumental average water price.

\subsection{Results}

The water demand function is estimated in double logarithm form using panel data methods for Andorra La Vella. All estimated coefficients can be interpreted as elasticities. Estimation results are presented in Table 3. In models (1)-(3), errors are clustered by street name, whereas, in models (4)-(6), street names are included as fixed effects.

When considering all types of family units together (single-family and multi-family units), the water price elasticity varies between -0.741 and -0.729 . This range of values is consistent with estimates reported for France and Spain in Table 1. The domestic water demand in Andorra La Vella is then inelastic. Facing a price increase by 10 percent, one can expect a reduction of the domestic water consumption by 7.3 to 7.4 percent. The water price elasticity is consistently found to be higher (in absolute value) for single-family units, in comparison with multi-family units. Considering for instance models (3) and (4) where street names are introduced as fixed effects, we report water price elasticity equal to -0.823 and -0.701 for single-family and multi-family units, respectively. This indicates that households are more reactive to a change in water price when they live in a single-family unit. As a robustness check of this result, we have again estimated model (4) by adding an interaction term between the logarithm of the instrumentalized average water price and a dummy variable for households in a single-family unit. The estimated coefficient for this interaction term is equal to -0.112 (significant at 1 percent) and the coefficient of $\ln$ Average price is equal in that case to -0.701 (significant at 1 percent): households in single-family units are more reactive to changes in water price than households in multi-family units, all being equal.

Seasonality is a strong characteristic of domestic water consumption in Andorra La Vella. The quarterly dummy variables are indeed highly significant in all models. Compared to the first trimester (January-March), a lower water consumption is found during trimester 2 (April-June), 3 (July-September) and 4 (October-December). This is not surprising given the fact that winter corresponds to the high skiing season when Andorra registers a peak in terms of visiting tourists. The lowest domestic water consumption is found from July to September, both for single-family units and for multi-family units. 
Table 3. Panel data regression. Dependent variable is logarithm of water consumption per family unit per quarter.

\begin{tabular}{|c|c|c|c|c|c|c|}
\hline & \multicolumn{3}{|c|}{ Errors Clustered by Street Name } & \multicolumn{3}{|c|}{ Street Names as Fixed Effects } \\
\hline & (1) & (2) & (3) & (4) & (5) & (6) \\
\hline & All Units & Single-Family & Multi-Family & All Units & Single-Family & Multi-Family \\
\hline \multirow[t]{2}{*}{ ln Average price ${ }^{a}$} & $-0.729 * * *$ & $-0.801^{* * *}$ & $-0.694^{* * *}$ & $-0.741^{* * *}$ & $-0.823^{* * *}$ & $-0.701^{* * *}$ \\
\hline & $(-15.86)$ & $(-6.75)$ & $(-12.58)$ & $(-39.43)$ & $(-15.37)$ & $(-38.13)$ \\
\hline \multirow[t]{2}{*}{ April-June ${ }^{b}$} & $-0.432^{* * *}$ & $-0.383^{* * *}$ & $-0.431^{* * *}$ & $-0.425^{* * *}$ & $-0.362^{* * *}$ & $-0.428^{* * *}$ \\
\hline & $(-13.21)$ & $(-5.75)$ & $(-11.61)$ & $(-13.47)$ & $(-3.93)$ & $(-13.97)$ \\
\hline \multirow[t]{2}{*}{ July-September $^{b}$} & $-0.619 * * *$ & $-0.467^{* * *}$ & $-0.643^{* * *}$ & $-0.615^{* * *}$ & $-0.449 * * *$ & $-0.643^{* * *}$ \\
\hline & $(-15.24)$ & $(-5.62)$ & $(-13.97)$ & $(-15.18)$ & $(-3.80)$ & $(-16.35)$ \\
\hline \multirow[t]{2}{*}{ October-December ${ }^{b}$} & $-0.202^{* * *}$ & $-0.151^{* * *}$ & $-0.210^{* * *}$ & $-0.200^{* * *}$ & $-0.151^{* *}$ & $-0.207^{* * *}$ \\
\hline & $(-14.82)$ & $(-3.74)$ & $(-13.17)$ & $(-12.72)$ & $(-3.29)$ & $(-13.53)$ \\
\hline ln Precipitation & $\begin{array}{c}0.0440^{* * *} \\
(4.32)\end{array}$ & $\begin{array}{c}0.0482 \\
(1.60)\end{array}$ & $\begin{array}{c}0.0394^{* *} \\
(3.02)\end{array}$ & $\begin{array}{c}0.0443^{* * *} \\
(4.21)\end{array}$ & $\begin{array}{l}0.0397 \\
(1.29)\end{array}$ & $\begin{array}{c}0.0421^{* * *} \\
(4.12)\end{array}$ \\
\hline \multirow[t]{2}{*}{ In Average temperature } & $0.643^{* * *}$ & $0.793^{* * *}$ & $0.586^{* * *}$ & $0.640^{* * *}$ & $0.776^{* * *}$ & $0.586^{* * *}$ \\
\hline & (13.09) & $(7.59)$ & $(12.31)$ & $(17.04)$ & $(7.08)$ & $(16.07)$ \\
\hline \multirow[t]{2}{*}{ In Family units } & $-0.314^{* * *}$ & & $-0.173^{*}$ & $-0.344^{* * *}$ & & $-0.272 * * *$ \\
\hline & $(-3.84)$ & & $(-2.20)$ & $(-15.57)$ & & $(-9.63)$ \\
\hline \multirow[t]{2}{*}{ Constant } & $2.249^{* * *}$ & $1.662^{* * *}$ & $2.141^{* * *}$ & $0.800 *$ & -0.933 & $2.064^{* * *}$ \\
\hline & $(10.84)$ & $(5.54)$ & (7.98) & $(2.03)$ & $(-1.20)$ & $(4.76)$ \\
\hline Observations & 33115 & 7090 & 26025 & 33287 & 7222 & 26065 \\
\hline
\end{tabular}

${ }^{a}$ intrumentalized average water price; ${ }^{b}$ reference is January-March; $t$ statistics in parentheses; ${ }^{*} p<0.05,{ }^{* *} p<0.01,{ }^{* * *} p<0.001$; The description of variables can be found in Table A1. 
Climatic conditions, in particular temperatures, appear to have a significant impact on domestic water consumption. The coefficient of $\ln$ Average temperature is always significant at 1 percent, with a range between 0.586 and 0.776 . Facing an increase of the average temperature by 10 percent, Andorran households will increase their water consumption by around 5.9 to 7.8 percent. Households in single-family units appear to be more impacted by temperatures than households in multi-family units. To check this result, we have again estimated models (1) and (4) by adding an interaction term between the logarithm of the average temperature and a dummy variable for households in a single-family unit. The estimated coefficient for this interaction term is equal to 0.297 for model (1) and to 0.301 for model (4) (both significant at 1 percent), and the coefficient of $\ln$ Average temperature is equal to -0.570 both for models (1) and (4) (significant at 1 percent): households in single-family units are more reactive to changes in temperature than households in multi-family units, all else being equal. This may be due to a larger share of recreative outdoor activities requiring water in single-family units (garden, swimming pool, etc.).

Lastly, a scale effect is documented. The water consumption per family unit tends to decrease with the number of family units per domestic water subscriber. On average, the larger a multi-family dwelling, the lower the water consumption per family unit. This result is consistent with the existing literature on multi-family housing. For example, analyzing water consumption in over 2300 multi-family buildings located in New York City, Kontokosta and Jain [30] show that there is a negative relationship between water use intensity (i.e., water consumption per square meter) and building size (in square meter), a proxy for the number of family units. More precisely, Kontokosta and Jain [30] report that, for every $10 \%$ of additional floor area, water use intensity decreases by approximately $0.8 \%$. A significant relationship between water use and building size is also found in [31-33].

\subsection{Policy Implications}

Based on the estimates presented in Table 1, it appears that households in single-family units differ significantly from households in multi-family units in terms of water price elasticity and in terms of how they react to changes in temperature. From a policy perspective, this raises the issue of whether or not to install individual meters in multi-family units, in order to implement individual pricing mechanisms.

Some empirical studies have been performed to measure the impact of these billing systems, and the effect of switching from collective to individual metering. For instance, in the southeast of England, a program performed in 2015 by the government, prompted the installation of nearly $500,000 \mathrm{~m}$. Before the program, only 40 percent of households were metered. Ornaghi and Tonin [34] have analyzed the impact of the program before the installation of the meters. Their analysis suggests that households are responding to the installation of meters by decreasing their consumption between 16 and 20 percent. Barraqué [35] reviews whether or not water utilities in France should individually meter multi-family houses, in Paris specifically. The author bases his analysis in France, but also examines some other countries and cities, such as England and Wales, New York City, Barcelona, Belgian Flanders and Wallonia, which have moved from collective to individual metering of domestic water use. In general, Barraqué [35] concludes that there is no need for water utilities to separately meter each household in a condominium building. If the concern is redistribution, there are possibilities to support low-income customers under collective metering.

In the Andorran context, a cost-benefit analysis of individual metering in multi-family units would still require additional work, for example regarding the cost of universal metering or understanding the factors influencing water demand for multi-family units (i.e., indoor or outdoor water use). 


\title{
6. Conclusions
}

Demand-side water management has become a crucial activity of water sector regulation in most countries. Even though Andorra is a water-rich country, a good understanding of the main drivers of residential water consumption (including water price) may be useful. Indeed, since an increase of water price is expected in the future, the way in which households adjust their water consumption may inform water utility managers and, more generally, public authorities in charge of water sector regulation.

Surprisingly, and to our best knowledge, no estimate of the residential water demand function in Andorra has yet been published. Our current work aims to fill this gap by providing the first estimate of the residential water demand function in Andorra. We have estimated an econometric model using a panel dataset covering the years 2006 to 2015 for the municipality of Andorra La Vella. Our estimates reveal a price elasticity of the residential water demand around -0.7 . Facing a price increase of 10 percent, households will react in the short run by reducing their water consumption by 7 percent. This result has important policy implications. Indeed, pricing reforms are often cited as the first measure to be implemented in order to signal water scarcity and to encourage a reasonable use of water. The effectiveness of any pricing policy in engaging water consumption depends, however, on the price elasticity of consumption. The larger the price elasticity, the more effective these policies are at reducing water consumption. Our estimate of the domestic water demand in Andorra allows decision-makers to simulate the impact of change in the water price on domestic water use. To achieve more significant reductions of household water consumption, public authorities in Andorra should complement their price policies with non-price policies, such as education or awareness campaigns.

We have also shown that Andorran households in single-family units differ significantly from households in multi-family units, for example in terms of water price elasticity and in terms of how they react to increases in temperature. From a policy perspective, this result calls for a differentiated treatment of households depending upon whether they live in single-family or in multi-family units. Finally, seasonality appears to be a strong characteristic of domestic water use in Andorra. This opens the door to consider more sophisticated pricing schemes such as time-of-use (TOU) water prices or peak pricing.

Acknowledgments: This work has been conducted within the partnership between the Principality of Andorra and the Institut d'Economie Industrielle (IDEI): financial support is acknowledged. Cristina Pesado Pons acknowledges a predoctoral grant from the Government of Andorra, ATC017-AND-2016/2017. We also thank the two anonymous referees of the Journal Water for their very helpful comments and suggestions.

Author Contributions: Arnaud Reynaud has conceived the analysis; Marc Pons and Cristina Pesado have provided the water consumption and pricing data; Arnaud Reynaud has analyzed the data; Arnaud Reynaud, Marc Pons and Cristina Pesado have written and revised the paper together.

Conflicts of Interest: The authors declare no conflict of interest.

\author{
Abbreviations \\ The following abbreviations are used in this manuscript: \\ MDPI Multidisciplinary Digital Publishing Institute \\ IBR Increasing Block Rate \\ OLS Ordinary Least Squares \\ IV Instrumental Variables \\ TOU Time-of-Use \\ IDEI Institut d'Economie Industrielle
}




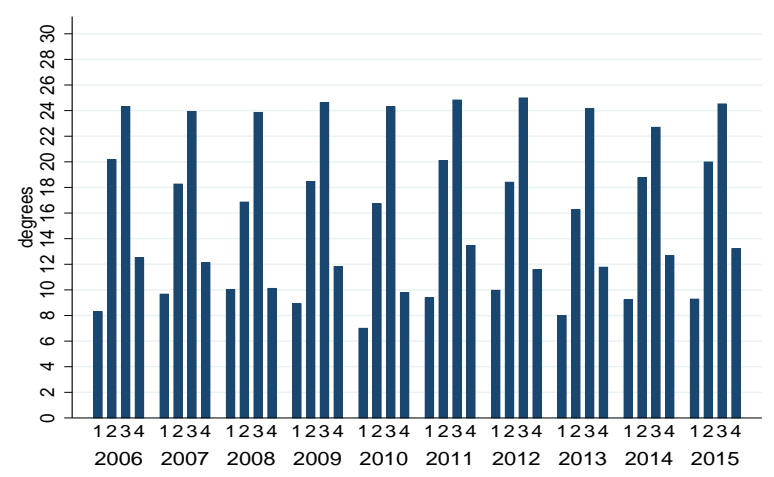

(a) Average daily maximal temperature (degrees).

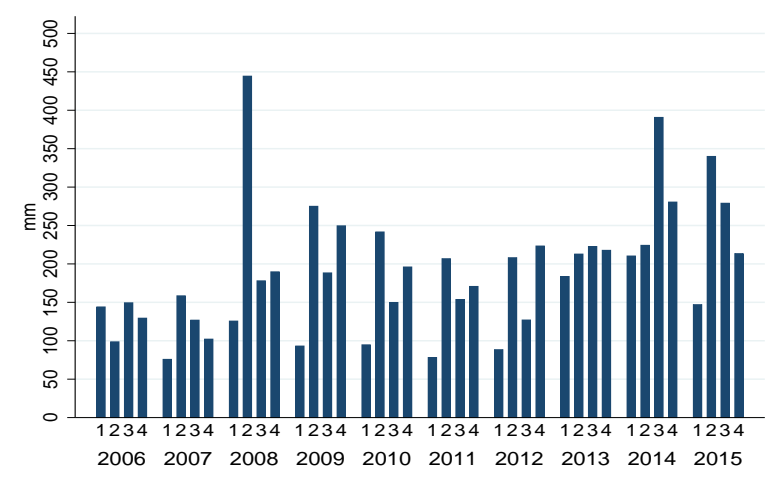

(b) Cumulated rainfall (mm per quarter).

Figure A1. Average of daily maximal temperature (degrees) and cumulated rainfall (mm per quarter) at the Roc de Sant Pere meteorological station. 1, 2, 3 or 4 for January-March, April-June, July-September and October-December, respectively.

\section{Appendix B. Data Description and Descriptive Statistics}

Table A1. Description of data used for estimating the domestic water demand function.

\begin{tabular}{|c|c|c|c|c|c|}
\hline Name & Definition & Mean & Std. Dev. & Min & Max \\
\hline $\mathrm{W}$ & Quarterly water consumption per family-unit (m3 per quarter per family unit) & 45.25 & 90.95 & 0 & 4,219 \\
\hline Average price & Instrumentalized average water price $\left(€\right.$ per $\left.\mathrm{m}^{3}\right)$ & 1.05 & 0.22 & 0.79 & 1.53 \\
\hline Precipitation & Quarterly rainfall (mm per quarter) & 190.11 & 80.45 & 75.80 & 444.40 \\
\hline Average temperature & Average of daily maximal temperature (degrees) & 15.87 & 5.99 & 7.00 & 24.98 \\
\hline Family units & Average number of family units per water subscriber & 10.86 & 13.36 & 1 & 159 \\
\hline
\end{tabular}

Source: Andorra Office of Statistics (precipitation, average temperature), Municipality of Andorra La Vella (W, average price, family units).

\section{References}

1. Organization for Economic Co-operation and Development (OECD). Water resources allocation: Sharing risks and opportunities, OECD studies on water; OECD Studies on Water OECD Publishing: Paris, France, 2015.

2. Hejazi, M.I.; Edmonds, J.; Clarke, L.; Kyle, P.; Davies, E.; Chaturvedi, V.; Wise, M.; Patel, P.; Eom, J.; Calvin, K. Integrated assessment of global water scarcity over the 21st century under multiple climate change mitigation policies. Hydrol. Earth Syst. Sci. 2014, 18, 2859-2883.

3. Arbués, F.; García-Valiñas, M.A.; Martínez-Espiñeira, R. Estimation of residential water demand: A state-of-the-art review. J. Socio-Econ. 2003, 32, 81-102. 
4. Worthington, A.C.; Hoffman, M. An empirical survey of residential water demand modelling. J. Econ. Surv. 2008, 22, 842-871.

5. The European Economic Agency (EEA). Assessment of cost recovery through water pricing; EEA Technical Report No. 16/2013; The European Economic Agency: Copenhagen, Denmark, 2013.

6. Govern of Andorra. Andorra in Figures 2015; Govern of Andorra: Andorra, Andorra La Vella, 2015.

7. Departament de Medi Ambient (DMA) del Govern d'Andorra. Estudi Per a L'elaboració Anyal del Balanc Hídric del Principat d'Andorra-Any 2015; Departament de Medi Ambient (DMA) del Govern d'Andorra: Andorra, Andorra La Vella, 2016.

8. Departament de Medi Ambient (DMA) del Govern d'Andorra. Estudi Per a L'elaboració Anyal de L'inventari I Quantificació de la Despesa Hídrica Per Usos del Principat D'Andorra-Any 2015; Departament de Medi Ambient (DMA) del Govern d'Andorra: Andorra, Andorra La Vella, 2016.

9. López-Moreno, J.; Zabalza, J.; Vicente-Serrano, S.; Revuelto, J.; Gilaberte, M.; Azorin-Molina, C.; Morán-Tejeda, E.; García-Ruiz, J.; Tague, C. Impact of climate and land use change on water availability and reservoir management: Scenarios in the Upper Aragón River, Spanish Pyrenees. Sci. Total Environ. 2014, 493, 1222-1231.

10. Wentz, E.A.; Wills, A.J.; Kim, W.K.; Myint, S.W.; Gober, P.; Balling, R.C., Jr. Factors Influencing Water Consumption in Multifamily Housing in Tempe, Arizona. Prof. Geogr. 2014, 66, 501-510, doi:10.1080/00330 124.2013.805627.

11. Sebri, M. A meta-analysis of residential water demand studies. Environ. Dev. Sustain. 2014, 16, 499-520.

12. Arbués, F.; Villanúa, I.; Barberán, R. Household size and residential water demand: An empirical approach. Aust. J. Agric. Resour. Econ. 2010, 54, 61-80.

13. Vallès-Casas, M.; March, H.; Saurí, D. Examining the reduction in potable water consumption by households in Catalonia (Spain): Structural and contingent factors. Appl. Geogr. 2017, 87, 234-244.

14. Nauges, C.; Reynaud, A. Estimation de la demande domestique d'eau potable en France. Rev. Econ. 2001, 52, 167-185.

15. Nauges, C.; Thomas, A. Long-run Study of Residential Water Consumption. Environ. Resour. Econ. 2003, $26,25-43$.

16. Garcia, S.; Reynaud, A. Estimating the benefits of efficient water pricing in France. Resour. Energy Econ. 2004, 26, 1-25.

17. Rinaudo, J.D.; Neverre, N.; Montginoul, M. Simulating the Impact of Pricing Policies on Residential Water Demand: A Southern France Case Study. Water Resour. Manag. 2012, 26, 2057-2068.

18. Binet, M.E.; Carlevaro, F.; Paul, M. Estimation of Residential Water Demand with Imperfect Price Perception. Environ. Resour. Econ. 2014, 59, 561-581.

19. Martínez-Espiñeira, R. Residential Water Demand in the Northwest of Spain. Environ. Resour. Econ. 2002, 21, 161-187.

20. Arbués, F.; Barberán, R.; Villanúa, I. Price impact on urban residential water demand: A dynamic panel data approach. Water Resour. Res. 2004, 40, doi:10.1029/2004WR003092.

21. García-Valiñas, M. Efficiency and Equity in Natural Resources Pricing: A Proposal for Urban Water Distribution Service. Environ. Resour. Econ. 2005, 32, 183-204.

22. Arbués, F.; Villanúa, I. Potential for Pricing Policies in Water Resource Management: Estimation of Urban Residential Water Demand in Zaragoza, Spain. Urban Stud. 2006, 43, 2421-2442.

23. Martínez-Espiñeira, R. An Estimation of Residential Water Demand Using Co-integration and Error Correction Techniques. J. Appl. Econ. 2007, 10, 161-184.

24. García-Valiñas, M.; Martínez-Espiñeira, R.; González-Gómez, F. Affordability of residential water tariffs: Alternative measurement and explanatory factors in southern Spain. J. Environ. Manag. 2010, 91, 2696-2706.

25. March, H.; Saurí, D. The Suburbanization of Water Scarcity in the Barcelona Metropolitan Region: Sociodemographic and Urban Changes Influencing Domestic Water Consumption. Prof. Geogr. 2010, 62, 32-45, doi:10.1080/00330120903375860.

26. March, H.; Perarnau, J.; Saurí, D. Exploring the Links between Immigration, Ageing and Domestic Water Consumption: The Case of the Metropolitan Area of Barcelona. Reg. Stud. 2012, 46, 229-244, doi:10.1080/ 00343404.2010.487859.

27. Pérez-Urdíales, M.; García-Valiñas, M.; Martínez-Espiñeira, R. Responses to Changes in Domestic Water Tariff Structures: A Latent Class Analysis on Household-Level Data from Granada, Spain. Environ. Resour. Econ. 2016, 63, 167-191. 
28. Romano, G.; Salvati, N.; Guerrini, A. Estimating the Determinants of Residential Water Demand in Italy. Water 2014, 6, 2929-2945.

29. Nieswiadomy, M.L.; Molina, D.J. Urban Water Demand Estimates Under Increasing Block Rates. Growth Chang. 1988, 19, 1-12.

30. Kontokosta, C.E.; Jain, R.K. Modeling the determinants of large-scale building water use: Implications for data-driven urban sustainability policy. Sustain. Cities Soc. 2015, 18, 44-55.

31. Domene, E.; Saurí, D. Urbanisation and Water Consumption: Influencing Factors in the Metropolitan Region of Barcelona. Urban Stud. 2006, 43, 1605-1623, doi:10.1080/00420980600749969.

32. Wentz, E.A.; Gober, P. Determinants of small-area water consumption for the city of Phoenix, Arizona. Water Resour. Manag. 2007, 21, 1849-1863.

33. Balling, R.C.; Gober, P.; Jones, N. Sensitivity of residential water consumption to variations in climate: An intraurban analysis of Phoenix, Arizona. Water Resour. Res. 2008, 44, doi:10.1029/2007WR006722.

34. Ornaghi, C.; Tonin, M. The Effect of Metering on Water Consumption_Policy Note; Economics Department, School of Social Sciences, University of Southampton: Southampton, UK, 2017.

35. Barraqué, B. Is individual metering socially sustainable? The case of multifamily housing in France. Water Altern. 2011, 4, 223-244.

(C) 2018 by the authors. Licensee MDPI, Basel, Switzerland. This article is an open access article distributed under the terms and conditions of the Creative Commons Attribution (CC BY) license (http://creativecommons.org/licenses/by/4.0/). 